\title{
An ERASMUS student exchange involving nodes from Belgium, Sweden, Colombia, Slovakia and Greece was organized during 2020
}

\author{
David R.A. Coornaert ${ }^{\boxplus}$, Cyril Radermecker, Ahmed Kanfoud \\ Haute Ecole en Hainaut, Mons, Belgium \\ Competing interests: DRAC none, CR none; AK none
}

Haute Ecole en Hainaut (HEH) is a university college in the Walloon region in Belgium. It is constituted of four different departments: Law \& Economy, Education, Social Sciences and, in concern here, "Science and Technology". The latest department organises four professionalising bachelor levels (3 years) and six engineering levels (5 years).

In September 2008, the HEH inaugurated a bachelor level in biotechnology, with Bioinformatics as finality. The first graduated students emerged in June 2011. During their last year, students legally have to accomplish a 13 weeks professional internship within companies (industrial or academic) as long as a personal work known as "bachelor thesis".

Soon, difficulties arose as to find internship hosting companies in such a specific field in Belgium. The idea emerged then to contact SLU's renowned former EMBnet president, Professor Erik Bongcam-Rudloff, to host two Erasmus-wannabes students. We agreed on a mixture project, where the subject of work given to the students would partly serve as an internship (view,

observe, imitate) and partly as a bachelor thesis (build, dig, develop).

The initiative that started in 2012 in Sweden is a complete reciprocal success. Many students followed up to Sweden and, thanks to Erik's recommendations, to Italy and Finland.

The year 2019-2020 saw six students leave Belgium toward EMBnet nodes in Sweden, Greece, Slovakia and Colombia.

During the EMBNet AGM 2020, it climaxed with a short (but intimidating) presentation of their work in Greece by two of these students.

We're very proud that, although initially HEH's bachelor in Bioinformatics, two former Erasmus students recently got their PhD (Axel Thieffry and Hadrien Gourlé), and that a third one is on the way (Renaud Vandamme).

This year, the $\mathrm{HEH}$ inaugurated an engineering degree in "Life Data Technology", whose first graduations are expected in June 2024. We're hence very demanding of future collaborations for these new students. 